\title{
The Effect of HRM Practices on Employee Organizational Citizenship Behavior in ICT Companies
}

\author{
Ananda Putra Fajar \\ Department of Business Administration, Faculty of \\ Administrative Science, Universitas Indonesia, \\ Depok, Indonesia \\ anandaputrafajar@gmail.com
}

\author{
Pantius Drahen Soeling \\ Department of Business Administration, Faculty of \\ Administrative Science, Universitas Indonesia, \\ Depok, Indonesia \\ pantiusdrahen@gmail.com
}

\begin{abstract}
The present era of globalization and technology have encouraged the human resource management (HRM) function to optimize strategy in dealing with challenges faced by the organization. With precious value and endless capabilities, the contribution of capable human resources practices is needed to support the strategic objectives of the company. In a sense of developing a broader organizational climate through the program people capability as a source of sustainable and highly competitive advantage in the organization, the progression of extra-role behavior activities has been developed in the form of supporting interactions and relations among employee and employers by helping each work unit running in the company more effectively. This

while the OCB variables were measured based on five major dimensions by Organ (1988). The analysis is on the active employees of PT Sigma Cipta Caraka (Telkomsigma) who had worked for at least a year in the company with the number of 243 employees. This study uses quantitative methods in collecting data with a questionnaire as a research instrument. The research data will be analyzed using descriptive statistic analysis, correlation, and regression analysis to test the relationship among variables. The results of this study provide an evidence that each dimension of HRM practices, with the exception of training, have a positive significance but no strong indication to encourage OCB activities showed by employees in the ICT company.
\end{abstract} study attempts to propose and analyze the effects of HRM practices on organizational citizenship behavior (OCB). The HRM practices variable were measured through the High-Involvement HRM Practices tool by Prieto and Pérez-Santana (2014),

\section{INTRODUCTION}

To gain a better understanding about the life of an organization whether it is a private sector or public sector, human resource management (HRM) acted as a personnel unity that is manifested in the form of human resources or employees as the part of assets owned by a company. From managerial perspectives, the notion of HRM act as a perspective to build a strategic management structure for the relationships of various job offerings [1]. HRM always played a critical role in facing various organizational challenges, which in turn takes some form of contribution from organizational
Keywords - HRM practices; ICT company; organizational citizenship behavior

management intended to support the strategic goals of the company.

When HR professionals gain a clear understanding of the organization's business objectives, they can turn those business goals into measurable human resources practices [2] The organizational changes in certain companies into more dynamic and complex environment tend to improve the resources in effectiveness and performance by achieving competitive advantage. Therefore, HRM practices had the ability to help the organization achieve some form of competitive advantage through support from individual human 
resource competencies that can add measurable value to the company [3].

The application of HRM practices are experienced by challenge to understanding the skills, knowledge, and motivation shown by employees, that by term leads to managerial evaluations to find out what are the most important factors to affect the behavior of employees [4] through a variety of ways leading towards certain strategies [5]. This creates support from employees by the form of a good behavior may deliver some form of explicit contributions, known as organizational citizenship behavior (OCB), which stated by Organ as individual behavior that is discretionary, not directly or explicitly recognized by the formal reward system'. OCB has been considerably important to organizational life that perhaps now more crucial then ever indicated by the increased level in global competition, emphasis on customer-oriented services, and job requirements that depends on team-based structures [6].

The current largest integrated information and communication technology (ICT) company in Indonesia is known by the name of PT Sigma Cipta Caraka (Telkomsigma). It is a subsdiary part of PT Telekomunkasi Indonesia Tbk (Telkom Indonesia Group) which operates in activities through professionally owned resources support in generating revenue engine through development programs in a sustainable manner and ongoing basis to provide the best service for customers in the form of strategic business partners and the public community.

Based on the exposure, then it takes special attention to grow and maintain the efficiency of HRM pratices on employees. The development of all lines within firms also involves human resources strategies in managing and improving organizational performance on every employee of the firm that allow them to decide how their jobs are performed [7]. These roles are required to be performed by the various business units within each organizational directorate through the policies of human capital as well as improving employees' end-to-end contribution through a program of performance evaluation which contributes to the success of an organization [8].

The adoption of high-performance HRM practices activities in a sustainable condition [9] will provide support for the premise that employee motivation and interactions directly affects knowledge sharing within the organization. The ability are shown and reinforced by the employee in the form of specific behaviors that are considered more important and effective when executed appropriately [10]. This form of citizenship behavior that is related within the improvement of organizational effectiveness [11] by high degree performance of both quality and quantity at work are capable to enchance the level of effectiveness and improving the organization ability to retain its employees [12] while at the same time reducing the turnover rate for employees [13].

According to initial research, the employees only focus on their job description and rarely help each other in solving work issues. Consequently, their cooperation is needed to reach more succcesful business goals. By creating a balance of organizational climate needed in terms of diversity and work situation, the company can improve a set of corporate value within the employees by establishing more positive environment through the people capability program. This ultimately leads employees to engage into higher levels of OCB as well as to led the desire into low turnover in organizations [14].

To summarize, HRM practices have played a key role of all decision-making strategy [15]. It allows organizations to formally augment effective helping routines employees have developed on their own [16]. High-involvement HRM practices also capable of bringing high 
engagement through the OCB activities outside a formal policy, where such behaviour may result in increased performance in more developed and effectively within the organization [13]. Therefore, this study will focus on areas of HRM practices applied in the ICT company, namely job design, staffing, training, compensation, performance appraisal, and participation. Then, by including direct effects on each variable of OCB could give practical insights on how to increase the work performance in accordance with signified principles of good corporate governance stated by the company.

\section{LITERATURE REVIEW}

\section{A. Organizational Ciitizenship Behavior}

Organizational citizenhip behavior (OCB) is defined as a concept required to understand behavioral cause of performance, an individual spontaneous behavior [17]. The notion of OCB was not specified as a main requirement of the organizational work, but regarded as a attitude of voluntary participation to improve the effectiveness of the organization.

OCB is reflected as something that is discretionary and does not belong in the form of official role or needs in the organization [18] so that individuals have a choice that can be favoured more to determine the job length in regards with effort, care, innovation, as well as productive attitude closely linked to discretionary behavior and associated with positive outcomes for the sake of efficiency and organizational performance [19].

Examples of OCB's at the workplace like volunteering for extra job activities, helping coworkers, and making positive comments about the company [10]. Such activities constitute the aspects of many previous research studies that classify these main operational dimensions of OCB, following the study of Organ
[20], namely: altruism, conscientiousness, sportsmanship, courtesy, and civic virtue.

\section{B. Human Resource Management Practices}

The way the human resources management approach is running through in a manner of strategic and coherent way to maximize contributions endowed with a range of productivity, quality and profitability through enhancement and support of a business strategy [21]. HRM practices include process that are developed and executed specifically by departments and human resources professionals [2] to perceive a form of enchanced performance and superior competitive basis for the better progress of the organization firms [15].

A series of HRM practices not only can produce a higher form of corporate performance, but may give impact directly against external and internal social networks of the top management teams [3]. Based on extensive review of the literature, the identify aspects of high-performance human resource practice during the process of company management and development to include: job design, staffing, training, compensation, performance appraisal, and participation [22]. These six aspects have different role and functions, as explained next:

Job design is the methods that management used to develop the content or material, including work assignments and analysis as well as the process of a working line [10] that is relevant up to organizational competitiveness which includes experience and motivation of individuals and working unit in the firm [21].

Staffing process aims to obtain people with appropriate skills, abilities, knowledge and experience that fit to fill the jobs in the organization [21]. Internally, the role of prospective employees referred in the magnitude of existing business units within decentralized 
operation activities are set to specified responsibilities for choosing new recruits [18].

Training may be applied in any organizations which specified the process through condition which people systematically acquire and improve the skills and knowledge needed to enhance job performance [23]. For training to be most effective, transfer of training may act as a tend to enable employees to measure the degree in more gain knowledge and skills elaborated in daily work activities.

Compensation is a stage where companies offer some form of incentives in extent through competence as individual, work group, and long-term performance [9]. Under any circumstances that companies will have to reward their employees according to their job-related performance [24] with compensation payments through pay-performance standards by size and base recommendations to generate valuable feedback on any resources invested [15].

Performance appraisal forms a systematic process from HRM practices to classify and sort the hierarchy into employees in carrying out the integration of beliefs, values, and actions on the actively work activities [21]. The purpose of performance appraisal scheme must be tend to build some additional relationships between the business line manager and employees to adopt into more respectable policies [25].

Participation activities provide the opportunity for employees to personally voice their discontent and make adjustments against the authority or the issue of the firm management [18]. which in turn would affect employee behavior against organizational processes through the "sense of belonging" or interchange information among each individuals [17].

\section{The effect of HRM practices on organizational citizenship behavior}

To adapt with a distinct set of needs in the current human resources environment, job design practices should be designed in more flexible way [26] in which the employee role structure can be modified to demonstrate extra discretionary behavior in support of peer activities to deliver better results within every working unit. The direct relationships between job design with extra role behavior was postulated by Krishnan, Alias, Ismail, and Kanchymalay [27] who find that direct effect of perceived work design characteristics, such as feedback, task significance, psychological demand, autonomy and social support to engage in OCB. Based on the discussion, the following hypotheses is proposed:

H1: Job design practice has a significant effect to organizational citizenship behavior.

The preparation of HRM practices in the company is connected to their staffing procedures needed for stimulate and reinforce the emergence of a necessary different behavior among employees [28]. Following this statement, Nasurdin, Ahmad, and Tan [29] found that the placement of staff in the firm including activities of recruitment, selection, and orientation can result in a more fitting and significant way against the service-oriented OCB's. Thus, the next following hypotheses is proposed:

$\mathbf{H}_{2}$ : Staffing practice has a significant effect to organizational citizenship behavior.

Company training program steers their employees to get some sort of a learning experience. However, with minimal effort to transfer the acquired knowledge, these perceptions lead to motivate various manifestation to implement some behavioral activities of OCB, as Turnipseed and Murkison [30] suggested can be beneficial, by provide additional training to improve productivity, direct engagement in activities outside the organization that lead to further 
development of their skills. Previous research findings proved that small and medium enterprises (SME's) can balance the implementation of training activities to encourage development of OCB [31]. To support the link, the following hypotheses is proposed:

H3: Training Practice has a significant effect to organizational citizenship behavior.

Compensation strategy has been developed by the company in terms of orientation program hoping to cultiving employees citizenship behavior towards the reward system [32]. When the employees give cooperative support within company line project, such act can be seen as appreciative form towards the satisfactory work performance, individually or in groups [33]. Previous research by Alkhatani suggest that employees who demonstrate a high level of OCB leads to more promotions and higher salary increments for the employee in terms of service period in the organization [24]. To support the explanation, the following hypotheses is proposed:

H4: Compensation practice has a significant effect to organizational citizenship behavior.

With the increasing demands to improve job performance with organizationally relevant tasks, Werner has noted the indication of citizenship performance was higher to include the weights to be applied in the form of appraisal practices when supervisors has made the overall appraisal results of employees [12]. Therefore, the mechanism of performance appraisal and feedback process needs to consider the impact of OCB [34]. Studies by Jain and Jain showed performance appraisal practices are significantly positively affected with OCB [35]. Based on the discussion, the following hypotheses is proposed:
H5: Performance appraisal practice has a significant effect to organizational citizenship behavior.

HRM practices provide job holders with the ability and opportunity to exercise a higher degree of perceived influence over task-related decision [16] that encourage more potential interaction with supervisors and fellow co-workers, and thus leads to more conducive work environment for employees to perform the discretionary form of OCB [36]. When employees are given the opportunity to participate in decision-making, it could affect the role of employees in a higher level of service to the customer and engagement in extra-role behavior [8]. Podsakoff, Mackenzie, Paine, and Bachrach find that participation is closely related to the aspects of civic virtue [13]. To support the link and discussion, the following hypotheses is proposed:

H6: Participation practice has a significant effect to organizational citizenship behavior.

Previous research has confirmed that individuals are more likely to demonstrate OCB with positive perception of recruitment, placement, training, education and career development are more likely to demonstrate, yet another case with the perception of support, communication, retention, as well as performance assessment that contrasted with OCB [37]. Another case in terms of high-performance work practices may potentially be able to reduce the lower level of utilization in high-discretion work environments (costumer services-based companies) by tapping employees' citizenship behaviours that have proved to be strong to influence organizational performance [38].

Gamage also gives the idea about the relationship between four elements of HRM practices (staffing, training, development \& performance management, and compensation management) have a very positive correlation towards the improvement of OCB on employees [31]. 
Based on the review, HRM practices as a whole may correlates significantly with OCB. Therefore, the following hypotheses are proposed:

H7: HRM practices has a significant effect to employee organizational citizenship behavior.

The following figure below shows the construct between variables based on the theoretical framework:

\begin{tabular}{|c|}
\multicolumn{1}{c|}{ HRM Practices $(\boldsymbol{X})$} \\
\hline Job Design (X1) \\
\hline Staffing (X2) \\
\hline Training (X3) \\
\hline Compensation (X4) \\
\hline Performance Appraisal (X5) \\
\hline Participation (X6) \\
\hline Independent Variable
\end{tabular}

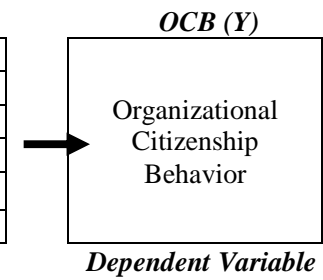

Fig. 1. Conceptual Model

\section{RESEARCH METHODS}

\section{A. Sample and data collection}

To see the more accurate picture related to the activities of daily employees in ICT companies, a survey research design was chosen for this study to collect the data for respective respondents from permanent employees of PT Sigma Cipta Caraka (Telkomsigma).
Their status indicates that they have been working at least for one whole year in the company. All respondents were informed that the survey was only used for academic purposes. The overall population is divided into four parts of the main business unit division, using techniques of cluster sampling to simplify the division of the population into 29 sub-business units.

Then, 286 employees were selected to fill out the questionnaires. The questionnaires were carried out to each selected respondent in a different section through the online forms or directly delivering the paper and collected them personally. The number of questionnaires returned consists of 234 sample employees yielding a valid response rate of 82 percent, which will be analyzed further using the program Statistical Package for Social Sciences (SPSS) version 20.

The list of information regarding the number of respondents is categorized into several characteristics, namely by gender, age, latest education, organizational position, and length/work tenure. The demographic profile of respondents is presented in table I.

TABLE I. DEMOGRAPHIC PROFILE RESPONDENTS ( $\mathrm{N}=234)$

\begin{tabular}{|c|c|c|c|}
\hline Variables & Category & Frequency & Percent \\
\hline Gender & Male & 146 & 62 \\
& Female & 88 & 38 \\
\hline Age (in years) & $<21$ & 2 & 0.9 \\
& $22-25$ & 39 & 16.7 \\
& $26-29$ & 63 & 26.9 \\
& $30-33$ & 57 & 24.4 \\
& $34-37$ & 32 & 13.7 \\
& $38-41$ & 21 & 9 \\
& $42-45$ & 9 & 3.8 \\
& $46-49$ & 9 & 3.8 \\
& $>50$ & 2 & 0.9 \\
\hline Education & High School & 10 & 4.3 \\
\hline
\end{tabular}




\begin{tabular}{|c|c|c|c|}
\hline & Certificate/diploma & 28 & 12.0 \\
& Bachelor degree & 181 & 77.4 \\
& Master degree & 15 & 6.4 \\
\hline $\begin{array}{c}\text { Organizational } \\
\text { Position }\end{array}$ & Senior Manager/Senior Specialist & 3 & 1.3 \\
& Manager/Specialist & 10 & 4.3 \\
& Assistant Manager/Senior Officer & 23 & 9.8 \\
& Supervisor/Officer & 43 & 63.7 \\
& Staff & 149 & 2.6 \\
\hline $\begin{array}{c}\text { Work tenure (in } \\
\text { years) }\end{array}$ & Non-Staff & 6 & 41.9 \\
& $1-3$ & 98 & 29.5 \\
& $4-6$ & 69 & 28.6 \\
\hline
\end{tabular}

\section{B. Measures}

In this study, questionnaire with fivepoint likert scale (strongly disagree $=$ " 1 ", strongly agree $=$ " 5 ") was used to indicate certain aspects of the research indicator. First, HRM practices involving each element specifically focused on the company's operational activities using as many as 29 statement items adapted from Prieto and Pérez-Santana [22] with Cronbach's Alpha reliability test showed very reliable results $(\sigma=0.947)$. The measurement analysis of each dimension of HRM practices is divided into job design ( 4 items, $\sigma=0,786)$, staffing ( 5 items, $\sigma=0,862)$, training ( 5 items, $\sigma=$ 0,834), compensation (4 items, $\sigma=0,931$ ) performance appraisal ( 5 items, $\sigma=0.903$ ), and participation ( 5 items, $\sigma=0.905$ ).

Second, organizational citizenship behavior (OCB) follows a dimension of Morrison Scale using as many as 21 statement items [28]. The measurement of Cronbach's Alpha reliability test showed very reliable results $(\sigma=0.905)$. The measurement analysis of each scope of each OCB dimension is divided into altruism $(7$ items, $\sigma=0.841)$, conscientiousness ( 5 items, $\sigma=0.688$ ), sportsmanship (3 items, $\sigma=0.902)$, courtesy ( 3 items, $\sigma=0.752$ ), and civic virtue ( 3 items, $\sigma=0.856$ ).

Measurement of correlation coefficient through cross-identification between variables is measured by using the pearson product moment. Simple regression analysis is used to see the direct effect of each research variables, and multiple regression analysis is used to test the research hypotheses in the form of t-test significance. The hypotheses will be accepted if the value of significance (sig) is smaller than the probability value at 95 percent significance level. Prior to testing, the effects of the control variables were also estimated in the form of sex, age, and job tenure which seems to have significant effects on employee OCB in the company (Morrison, 1994). To further understand the diversity in the high-performance HRM practices activities that are assumed to engage employee OCB, the following information from coefficient of determination were also measured. 


\section{RESULTS}

\section{A. Descriptive Statistics and Inter Correlation Variables}

Means, standard deviations, and correlations among the study variables are reported in table II, indicate positive correlations were observed between each set of HRM practices activities and OCB. Consequently, it is evident that all correlation values appear to be significant at 0.01 level. Hence it can be assumed that different dimensions of HRM practices are not only significantly related to OCB but are also positively related to each other. The strongest correlation value is 0.501 between staffing practices and OCB, which signifies there is a qualified ability demonstrated in a company to create OCB activities in fullness to the work of management.

The obtained results also reflected on other dimensions (job design, staffing, compensation, performance appraisal, dan participation) of HRM practices that is moderately have an effect to elicit OCB. However, training program found to had the lowest correlation value with OCB ( $\mathrm{r}=$ 0.320). This indicates that companies are unable to ensure the growth of additional work behaviors if the training program does not capable of conserving more interaction within employees in the workplace.

TABLE II. CORRELATION MATRIX

\begin{tabular}{|l|c|c|c|c|c|c|c|c|c|c|c|c|}
\hline & $\mathbf{M}$ & $\mathbf{S D}$ & $\mathbf{1}$ & $\mathbf{2}$ & $\mathbf{3}$ & $\mathbf{4}$ & $\mathbf{5}$ & $\mathbf{6}$ & $\mathbf{7}$ & $\mathbf{8}$ & $\mathbf{9}$ & $\mathbf{1 0}$ \\
\hline 1. OCB & 3,90 & 9.262 & 1 & & & & & & & & & \\
\hline 2. Job Design & 3,86 & 2.297 & $.448 * *$ & 1 & & & & & & & & \\
\hline 3. Staffing & 3,92 & 2.700 & $.501 * *$ & $.521 * *$ & 1 & & & & & & & \\
\hline 4. Training & 3,42 & 4.024 & $.320 * *$ & $.425 * *$ & $.461 * *$ & 1 & & & & & & \\
\hline 5. Compensation & 3,62 & 2.795 & $.436 * *$ & $.368 * *$ & $.435 * *$ & $.435 * *$ & 1 & & & & & \\
\hline $\begin{array}{l}\text { 6. Performance } \\
\text { Appraisal }\end{array}$ & 3,75 & 3.098 & $.449 * *$ & $.472 * *$ & $535^{* *}$ & $495 * *$ & $.549 * *$ & 1. & & & & \\
\hline 7. Participation & 3,74 & 3.029 & $.475 * *$ & $.447 * *$ & $.492 * *$ & $.456 * *$ & $.480 * *$ & $.565 * *$ & 1 & & & \\
\hline 8. Gender & 1.38 & .485 & -.059 & -0.037 & -0.053 & $-.161 *$ & -0.018 & 0.033 & -0.005 & 1 & & \\
\hline 9. Age & 31.54 & 6.554 & $.190 * *$ & 0.092 & 0.059 & 0.061 & $.174 * *$ & 0.026 & 0.086 & -0.09 & 1 & \\
\hline 10. Work Tenure & 1.87 & .831 & 0.069 & -0.032 & $-.134 *$ & -0.111 & 0.017 & -0.125 & -0.026 & -0.046 & $.585 * *$ & 1 \\
\hline
\end{tabular}

Between the control variables, negative correlations were obtained between OCB and gender $(\mathrm{r}=-0.059)$ while the other elements showing results between OCB and age $(r=0.190)$ and thus OCB and work tenure $(r=0.069)$. From the list of demographic variables included, it has not been proven to be sufficient to positively affect the emergence of OCB. Then, given interpretation based on correlation results shows the interaction effect that able to predict other factors between two research variables more significantly [40].

\section{B. Hypotheses Testing}

H1: According to the information from table III, job design is significantly related with OCB $(\beta=1.805, \mathrm{p}<0.05)$ which explain variance of managing work design to affect employes in engaging OCB activities by 19.7 percent $\left(\triangle R^{2}=0.197\right)$. Thus, $\mathrm{H}_{1}$ is supported. 
H4: According to the information from table III, compensation is significantly and positively related with OCB $(\beta=1,445, \mathrm{p}$ $<0.05)$ which explain variance of compensation and benefits models to affect employes in engaging OCB activities by 18.7 percent $\left(\Delta \mathrm{R}^{2}=0.187\right)$. Thus, $\mathrm{H}_{4}$ is supported.

H5: According to the information from table III, performance appraisal is significantly and positively related with OCB $(\beta=1.343, p<0.05)$ which explain variance of managing the ratings of employee to affect them in engaging OCB activites by 19.8 percent $\left(\triangle R^{2}=0.198\right)$. Thus, $\mathrm{H}_{5}$ is supported.

TABLE III. SIMPLE REGRESSION RESULTS BASED ON THE DIMENSIONS ( $\mathrm{N}=234)$

\begin{tabular}{|ccccc|}
\hline Independent Variable & \multicolumn{3}{c|}{ Dependent Variable $^{\mathrm{a}}$} \\
\hline Intepretation & $\beta$ & Adjusted R Square & $t$ & Sig. $^{*}$ \\
\hline Job Design (X1) & 1.805 & 0.197 & 7.629 & $0,000^{\mathrm{b}}$ \\
\hline Staffing (X2) & 1.719 & 0.248 & 8.882 & $0,000^{\mathrm{b}}$ \\
\hline Training (X3) & 735 & 0.098 & 5.137 & $0,000^{\mathrm{b}}$ \\
\hline Compensation (X4) & 1.445 & 0.187 & 7.383 & $0,000^{\mathrm{b}}$ \\
\hline Performance Appraisal (X5) & 1.343 & 0.198 & 7.660 & $0,000^{\mathrm{b}}$ \\
\hline Participation (X6) & 1.454 & 0.223 & 8.232 \\
\hline b. Predictors: (Constant), Participation, Job Design, Compensation, Training, Staffing, Performance Appraisal (Not as Stimultant)
\end{tabular}

H6: According to the information from table III, participation is significantly and positively related with OCB $(\beta=1,454, p$ $<0.05)$ which explain variance of active employees can affect in engaging OCB activites by 22.3 percent $\left(\Delta \mathrm{R}^{2}=0.223\right)$. Thus, $\mathrm{H}_{6}$ is supported.

TABLE IV. MULTIPLE REGRESSION RESULTS BASED ON THE DIMENSIONS ( $\mathrm{N}=234)$

\begin{tabular}{|c|c|c|c|c|}
\hline \multirow{2}{*}{$\begin{array}{c}\text { Independent Variable } \\
\text { Intepretation }\end{array}$} & \multicolumn{4}{|c|}{ Dependent Variable ${ }^{a}$} \\
\hline & $\beta$ & Adjusted $R$ Square & $t$ & Sig. \\
\hline (Constant) & 34.904 & 0,354 & 8.416 & $0.000^{\mathrm{b}}$ \\
\hline Job Design (X1) & 0.682 & & 2.577 & $0.011^{\mathrm{b}}$ \\
\hline Staffing (X2) & 0.803 & & 3.37 & $0.001^{\mathrm{b}}$ \\
\hline Training (X3) & -0.127 & & -0.841 & $0.401^{\mathrm{b}}$ \\
\hline Compensation (X4) & 0.545 & & 2.473 & $0.014^{\mathrm{b}}$ \\
\hline Performance Appraisal (X5) & 0.222 & & 1.004 & $0.316^{\mathrm{b}}$ \\
\hline Participation (X6) & 0.578 & & 2.731 & $0.007^{b}$ \\
\hline
\end{tabular}

a. Dependent Variable: Organizational Citizenship Behavior ${ }^{b}$ Predictors: (Constant), Participation, Job Design, Compensation, Training, Staffing, Performance Appraisal 
Result of multiple linear regression shown in table IV is adequate and significant. Overall, staffing has the most positive beta values $(\beta=0.803 ; p<0.001)$ with a trend of direct relationship indicates that selecting staffing are the highest set of HRM practices internally performed in choosing employees who might give more performers in the company (Gupta and Singh, 2010) thereby generating greater opportunities for the OCB process by integrate employees into each of their existing business unit. In contrast, the results of the third regression coefficient (X3) indicate the practice of training has the most negative beta values $(\beta=-0.032$; $\mathrm{p}<0.001)$ with a tendency to the opposite relationship. These results indicate that training programs do not necessarily have any effect to enchance OCBs from employees, where activities such as mentoring between employees are less likely to link up with a bigger challenge of operational goals in each of uniformly business units in the company.

H7: Based the multiple regression analysis from table IV, HRM practices have positively related with OCB which explain variance in engaging employees OCB to be precisely 35.4 percent $\left(\Delta \mathrm{R}^{2}=\right.$ 0.354 ). Consequently, by having t value of 8.416 (sig. $=0,000)$, these results indicate that the derivative dimensions of HRM practices performed by the stimulate force will have a significant effect on OCB employees in the company. These finding suggests that $\mathrm{H}_{7}$ is supported.

\section{DISCUSSION}

The aim of this study was to place the relationship between two constructs HRM practices and Organizational citizenship behavior (OCB) on ICT companies. Related to current conditions in the organization, employees are always able to accept and implement encouragement in doing business to ensures the improvement of infrastructure and technology supported by business lines related to the quality development and trusted end-to-end services that is beneficial to the achievement of results in the company, that is, through the calculation of HRM practices that have been prepared in such a way and can reduce the time spent on activities against things that are profitable personally [41].

HRM practices such as competitive compensation, extensive benefits, and job security may help attract capable employees and retain them in organizations, and practices such as work teams, employee involvement, and flexible job design may provide employees with opportunities to share knowledge and to learn new skills [42]. However, in a way, firms tend to not arrange their management by demonstrated practice, but rather by attention of positive perception that are shown by the individual in the company [30].

If there is a certain perception by the individual to be more involved with his work, then at the same time there will be a high tendency to enforce the OCB and stay in the organization [14]. A similar study was conducted by Gamage who says the effective use of HRM practices are capable of influence positive behavior that is represented through the form of organizational commitment which in turn leads to an increase in employee OCB's for the necessary achievement of organizational success [31].

Current research studies also provided support for the empirical analysis conducted descriptively to see the potential of additional behavior generated through activities related to human resources in the company which shows a high number of employees who are willing to tolerate in helping fellow colleagues and making progress in line of operations on a regular basis. The existing behavioral literatures and trends will not only impact the progress of the company business strategies, but would also increase productivity and make employees feel 
valued and enhance them to the occurrence of a higher commitment and OCB [37].

In the sense of the organizational management within the fast-forward companies, they may object to direct the career planning activities in more job design-oriented. First, by focusing into skills or qualifications needed to reach the expected awareness on increasing work line effectiveness so that the employees are more able to integrate the values applied by their company. Second, by increasing the frequency of on-site training programs that allowed other employees to conduct on extra behavior by further range of unstructured work cultures through a new method of knowledge sharing, as well as to exploring the feedback assessment and direct criticism from their superiors.

Future research may tend to view on causal inferences that not only come from organizational support, but also through their own individual characteristics. This is because while subjecting focus on industry with different fields and backgrounds, it could reduce the boundaries between company line and employees, while at the same time provide a tendency to predict distinct form of behaviors that is useful in doing the work through both individual and group in the sense of empowering human resource practices to create an even more positive relationship in the integrated companies.

\section{CONCLUSION}

HRM practices involving certain facets in human resources activities, such as job design, staffing, training, performance appraisal, compensation, and participation which applied by the employees of the company are relatively high, because it generally stimulates OCB among employees, which is genuinely accepted to generate the effectiveness of work units and simultaneously affect the values and corporate cultures. The findings suggest that each employee participation can be depicted by staffing practices which has shown as the highest level of HRM practices to encourage OCB. On the other hand, training practice have the opposite tendency to deliver OCB.

Overall, the activities of HRM practices at the integrated companies is proved to have significant influence towards OCB on their employees. However, each component has no strong indication to support the discretionary activities of the designating tendency for other factors which can predict OCB produced by employees.

\section{REFERENCES}

[1] P. Boxall, "The Strategic Hrm Debate and the Resource-Based View of the Firm," Human Resource Management Journal, 6(3), 1996, pp. 59-75.

[2] D. Ulrich, "Measuring Human Resources: An Overview of Practice and a Prescription for Results," Human Resource Management, 36(3), 1997, pp. 303-320.

[3] C.J. Collins and K.D. Clark, "Strategic human resource practices, top management team social networks, and firm performance: The role of human resource practices in creating organizational competitive advantage," Academy of Management Journal, 46(6), 2003, pp. 740-751.

[4] G. Dreher and T. Dougherty, Human Resource Strategy: A Behavioral Perspective for the General Manager, Singapore: McGraw Hill/Irwin, 2002.

[5] D.E. Bowen and C. Ostroff, "Understanding HRM-firm performance linkages: The role of the "strength" of the HRM system," Academy of Management Review, 29(2), pp. 203-221.

[6] N.E. Fassina, D.A. Jones, and K.L. Uggersley, "Meta-analytic tests of relationships between organizational justice and citizenship behavior: testing agent-system and sharedvariance models," Journal of Organizational Behavior, 29(2), 2008, pp. 805-828.

[7] M. Huselid, "The impact of Human Resource Management practices on turnover, productivity, and corporate financial performance," Academy of Management Journal, 38(3), 1995, pp. 635-872.

[8] M.C. Gavino, S.J, Wayne, and B. Erdogan, "Discretionary and transactional human resource practices and employee outcomes: The role of perceived organizational support," 
Human Resource Management, 51(5), 2012, pp. 665-686.

[9] D. Jimenez-Jimenez and R. Sanz-Valle, "Studying the effect of HRM practices on the knowledge management process," Personnel Review, 42(1), 2013, pp. 28-49.

[10] F. Luthans, Organizational Behavior: An Evidence-Based Approach, $12^{\text {th }}$ ed., New York: McGraw-Hill, 2011

[11] Y.B. Truckenbrodt, "The Relationship between Leader-Member Exchange and Commitment and Organizational Citizenship Behavior," Acquisition Review Quarterly, 7(3), 2000, pp. 233-244.

[12] Werner, J. M. (2000). Implications of OCB and Contextual Performance for Human Resource Management. Human Resource Management Review, 10(1), 3-24.

[13] P.M. Podsakoff, S.B. Mackenzie, J.B. Paine, D.G. Bachrach, "Organizational Citizenship Behaviors: A Critical Review of the Theoretical and Future Research. Journal of Management, 26(3), 2000, pp. 513-563.

[14] K. Alfes, A. Shantz, C. Truss, and E. Soane, E, "The link between perceived human resource management practices, engagement and employee behavior: a moderated mediation model," International Journal of Human Resource Management, 24(2), 2013, pp. 330-351.

[15] R.A. Noe, J.R. Hollenbeck, B. Gerhart, P.M. Wright, Human Resource Management: Gaining A Competitive Advantage, 9 $^{\text {th }}$ ed., New York: McGraw-Hill, 2015

[16] K.W. Mossholder, H.A. Richardson, R.P. Settoon, "Human Resource Systems and Helping in Organizations: A Relational Perspective," Academy of Management Review, 36(1), 2011, pp. 33-52.

[17] Kaswan, Sikap Kerja: Dari Teori dan Implementasi Sampai Bukti, Bandung: Penerbit Alfabeta, 2015.

[18] M. Armstrong, A Handbook of Human Resource Management Practice, $10^{\text {th }}$ ed., Kogan Page Limited, Cambridge University Press, Cambridge, 2006.

[19] S.J. Hutchinson, Performance Management, London: CIPD Publishing. 2013.

[20] D.A. Kusumajati, "Organizational Citizenship Behavior (OCB) Karyawan Pada Perusahaan," Jurnal Humaniora, 5(45), 2014, pp. 62-70.

[21] J. Bratton and J. Gold, "Human Resource Management: Theory and Practice, $2^{\text {nd }}$ Edition. London: Macmillan Press, 1999.

[22] I.M. Prieto and M.P. Pérez-Santana, "Managing Innovative Work Behavior: The
Role of Human Resource Practices," Personnel Review, 43(2), 2014, pp. 184-208.

[23] J. Greenberg and R.A. Baron, Behavior in Organizations, $8^{\text {th }}$ ed., New Jersey: Prentice Hall, Inc., 2002.

[24] A. Alkahtani, "Organizational Citizenship Behavior (OCB) and Rewards". International Business Research, 8(4), 2015, pp. 210-222.

[25] S. Tyson, Essential of Human Resource Management, $5^{\text {th }}$ ed., Burlington: ButterworthHeinemann Publications, 2006.

[26] D.E Guest, "Human resource management and performance: a review and research agenda," The International Journal of Human Resource Management, 8(3), 1997, pp. 263-276.

[27] R. Krishnan, M.A. Alias, S. Ismail, S, and K. Kanchymalay, "The Influencing Role of Work Design Characteristics on Extra Role Performance of Employees," World Journal of Management Vol. 5 No. 2, 5(2), 2014, pp. 113.

[28] R.S. Schuler and S.E. Jackson, "Linking Competitive Strategies with Human Resource Management Practices," Academy of Management Executive, 1(3), 1987, pp. 207219.

[29] A.M. Nasurdin, N.H. Ahmad, C.L. Tan, "The role of staffing and orientation practices in predicting service-oriented organisational citizenship behavior," Asian Academy of Management Journal, 21(2), 2016, pp. 27-51.

[30] D. Turek and A. Wojtczuk-Turek, "HRM Practices Influence Organisational Citizenship Behavior? Mediating the Role of PersonOrganisational Fit," Management Knowledge and Learning Joint International Conference, 2015, pp. 2219-2233.

[31] A.S. Gamage, "Organizational Citizenship Behaviour among Employees in SMEs in Japan: An Analysis of the Link with HRM Practices," Kindai Management Review, 2(1), 2014, pp. 17-31.

[32] D.W. Organ, Organizational Citizenship Behavior - The Good Soldier Syndrome, $1^{\text {st }}$ ed., Lexington, Massachusetts/Toronto: D.C. Heath and Company, 1988

[33] S.B. MacKenzie, P.M, Podsakoff, and N.P. Podsakoff, "Challenge-oriented organizational citizenship behaviors and organizational effectiveness: Do challenge-oriented behaviors really have an impact on the organization's bottom line?" Personnel Psychology, 64, 2011, pp. 559-592.

[34] K. Rose, "Examining Organizational Citizenship Behavior in the Context of Human Resource Development: An Integrative Review of the Literature," Human Resource 
Development Review, 15(3), 2016, pp. 295316.

[35] S. Jain, and R. Jain, "Organizational Citizenship Behaviour and HRM Practices in Indian Banks," The Indian Journal of Industrial Relations, 50(2), 2014, pp. 257269.

[36] E. Snape and T. Redman, "HRM practices, organizational citizenship behaviour, and performance: A multi-level analysis," Journal of Management Studies, 47(7), 2010, pp. 1219-1247.

[37] K. Chang, B. Nguyen, K-T Cheng, C-C Kuo, and I. Lee, "HR practice, organisational commitment and citizenship behaviour: A study of primary school teachers in Taiwan," Employee Relations, 38(6), 2016. pp. 907-926.

[38] L. Sun, S. Aryee, and K.S. Law, "HighPerformance Human Resource Practices, Citizenship Behavior, and Organizational Performance: A Relational Perspective," Academy of Management Journal, 50(3), 2007, pp. 558-577.
[39] R. Aldag and W. Reschke, "Employee Value Added: Measuring Discretionary Effort and Its Value to the Organization," New York: Center for Organizational Effectiveness Inc., 1997, pp. 1-8.

[40] E.W. Morrison, "Role definitions and Organizational Citizenship Behavior: The importance of the employee's perspective," Academy of Management Journal, 37(6), 1994, pp. 1543-1567.

[41] Y-C, Wei, H, Tzu-Shian and H. I-Chieh, "High-performance HR practices and OCB: a cross-level investigation of a causal path," The International Journal of HumanResource Management, 9(10), 2010, pp. 1631-1648.

[42] K. Jiang, D. Lepak, J. Hu, and J. Baer, "How Does Human Resource Management Influence Organizational Outcomes? A Meta-Analytic Investigation of Mediating Mechanisms," Academy of Management Journal, 55(6), 2012, pp. 1264-1294. 